\title{
ISLAMIST EXTREMISM IDEOLOGY REHABILITATION PROGRAMS: A CRITICAL ANALYSIS
}

\author{
Rahimin Affandi Abdul Rahim ${ }^{1, *}$, Mohd Imran Abdul Razak ${ }^{2}$, Mohd Anuar Ramli ${ }^{1}$, \\ Siti Maimunah Binti Kahal ${ }^{3}$ \\ ${ }^{1}$ Dept. of Fiqh and Usul, Academy of Islamic Studies, Universiti Malaya, 506030 Kuala Lumpur, MALAYSIA.
${ }^{2}$ Academy of Contemporary Islamic Studies, UiTM Perak Branch, 32610 Seri Iskandar, Perak, MALAYSIA.
${ }^{3}$ Academy of Contemporary Islamic Studies, UiTM Shah Alam Branch, 40450 Shah Alam, Perak, MALAYSIA.
}

\begin{abstract}
The September 11 attacks gave an immense impact on Muslims worldwide. Governments, both Islamic and Western took matters regarding terrorism even more seriously. The incident too, however, became a stepping stone for Muslim terrorists to be louder. Nevertheless, terrorism among Muslims have always existed in the doctrine of certain sects, Salafi Jihadi in particular. Such extreme and radical misconceptions of Islam is inherited by their predecessor, the Khawarij. The study discusses the rehabilitation programs for those affected by extremism in Malaysia, and the regional guidelines for counter terrorism. The root cause for Islamist extremism is also analysed, along with the influence of Khawarij ideology on Salafi Jihadi, the similarities shared by both, particularly with regards of jihad.
\end{abstract}

Keywords: Salafi Jihadi; Khawarij; jihad; extremism; rehabilitation programs

\section{Introduction}

On the 23rd of June 2016, a video titled Thought, by Mohd Rafi, a Daesh member from Malaysia gave a rather bold statement. Targeting for the Muslims in Malaysia, he deliberately mentioned, "if you have a car, hit them. Use firearms or knives". He also warned the Royal Malaysian Police, Polis Diraja Malaysia (PDRM) "to those of you in Bukit Aman, you are no longer in aman (peace). We are ready to slaughter you. When we come, our allies in this country are hunting you too" (Haziq Jani 2017).

This statement is one of the many examples of the boldness and discourtesy of the extremists in Malaysia. This study henceforth focuses on the rehabilitation of such extreme ideology, which is related to Islam. For that, there will be two main parts, the first is on rehabilitation programs in Saudi, Singapore, and Malaysia. The second part of the study is a critical analysis on the factors leading to such extreme ideology.

\footnotetext{
* Corresponding author: faqir_ila_rabbih@um.edu.my eISSN: 2636-9265 CUniversiti Malaya Centre for Civilisational Dialogue, 2021 DOI: https://doi.org/10.22452/KATHA.vol17no1.4
} 


\section{Threats of Muslim Terrorists}

The Muslim community of this day are troubled by major issues, one of the many being deterioration leading to dependence on western countries. Worse still, extremism related to Islam has given the religion a more difficult time. The chain of reactions post 9/11 proved the consequences, how the west retaliates to every misconduct by Islamist extremists, sadly on the Muslims who disagree with the Islamist extremists themselves.

The Bali bombing incident, for example, sparked a series of more bombings in Indonesia (Azyumardi Azra 2003). Throughout 2000-2005, there had been many bombings such as in J.W. Marriot Hotel in 2003, Australian Embassy in 2004, and the second Bali bombing in 2005.

According to a study conducted in Singapore by Bilveer Singh (2017), the people in Southeast Asia assumed that the influence of Jemaah Islamiah (JI) and al-Qaeda (AQ) was already ended, with the death, capture, and silence of the faces of JI. Mentioned in his report:

"By 2011, however, JI appeared to have been severely degraded with its key military and ideological leaders either dead or detained; some broke away to form splinter groups. Among those killed or executed included operatives such as Azahari Husin (2005), Imam Samudra (2008), Nordin M Top (2009), and Dulmatin (2010). Leaders under detention include Abu Bakar Bashyir, Hambali, and Abu Dujana. The organisation's structure and networks were also believed to have been severely disrupted.

Globally, Abu Bakr al-Baghdadi's IS having superseded AQ as the leading global jihadi movement and key security threat. The killing of Osama bin Laden in 2011, and expansion of IS in Iraq and Syria culminating in the declaration of a caliphate in June 2014, have eroded AQ's position as the base of jihad. In Southeast Asia, especially in Indonesia, Malaysia, and Singapore, counter-terrorism measures are believed to have crippled JI and rendered it ineffective. In Indonesia alone, more than $110 \mathrm{JI}$ members have been killed and 1,200 imprisoned."

The Southeast Asian community assumed the total disappearance of JI influence. On this matter, Singh warned about the inaccuracy of this assumption. A recent interview with Abu Rushdan, exposed how JI also benefited along with ISIL's wide expansion. A number of factors facilitated the continued survival and revival of JI in general, and in Indonesia in particular. These are:

1. AQ central organisation under Ayman Zawahiri ‘s leadership continue to exist and even expand with territorial gains in Afghanistan, Pakistan, Yemen, and parts of Africa, including Libya and Somalia. This provides inspiration and hope to AQ alumni, comprising veterans and loyalists among JI followers. 
2. Pro-AQ and JI leaders continue to operate and remain steadfast in their loyalty to AQ and JI in Indonesia. They include Abu Rusydan, Zarkasih, Abu Jibril, Abu Tholut, Irfan Awwas, Abu Dujana and others.

3. The continued existence of JI members and networks in Indonesia, with most of the group's detainees scheduled to be released in the next few years.

4. JI members continued belief in and support for international jihad, with many Indonesians fighting with Jabhat al-Nusra (JAN), an AQ franchise, in Syria and Iraq. One of Abu Jibril's sons, Muhammad Ridwan, died fighting for JAN in March 2015. Abu Rusydan has also admitted that his group was providing humanitarian assistance to people in Iraq and Syria.

5. The continued running of many JI publishing houses, through Majlis Mujahidin Indonesia, with magazines such as Risalah Mujahideen and Syamina being produced on a regular basis.

6. Many pro-JI mosques and madrasahs in Indonesia, such as the one in Ngruki (Central Java), have continued to function and even expand.

7. The willingness of JI leaders to learn from the past failures of the group, aswell as other like-minded groups, such as Darul Islam and Komando Jihad, which were neutralised by the security apparatus.

The statements above are indeed frightening and call for a proper plan of action by those in power in Southeast Asia. One of those being well prepared with rehabilitation programs.

\section{Extremism Rehabilitation Programs}

Extremism rehabilitation programs that have proved effective in this modern era can be found in Saudi Arabia, Singapore, and Malaysia (Ezzraqui 2010). Essentially these programs are in two forms: deradicalization and disengagement. The former refers to the separation of an individual either voluntarily or forcefully from a radical ideology. The latter on the other hand, refers to the separation and the distancing of an extremist from the individual's group, even if it does not affect the individual's extreme ideology. The models used in these three countries involve both hard and soft approach.

\section{Rehabilitation Programs' Modus Operandi}

The rehabilitation programs require the authority to:

1. Trace, pry and detain.

2. Collect information on the details of an extremist ideology and its source.

3. Deradicalize detainees.

4. Gain support from the extremists' family members.

5. Keep track on released detainees.

6. Make use of the internet to expose of extreme ideologies and extremist groups (Mohd Mizan 2009).

By the end of the programs, a few actions will be taken:

1. The individuals will be returned to society, with social and economic support. 
2. The individuals usually tend to expose the wrongs in the ideology and help expose the community on such matter.

3. The deradicalized individuals' experience will be used to help those still in rehabilitation.

\section{Malaysian Government's Approach on Handling Muslim Extremism}

Basically, the approach used by the Malaysian government is similar to those used by Saudi Arabia and Singapore (Boucek 2008; Ramakrishna 2009). The differences are only in the agencies in charge. In Malaysia, these programs are entrusted to PDRM, KDN (Kementerian Dalam Negeri) and JAKIM (Jabatan Kemajuan Islam Malaysia) (Mohd Aslam 2016).

The PDRM investigates and detains using the SOSMA Act (Akta Kesalahan Keselamatan (Langkah-Langkah Khas) 2012). JAKIM, PDRM and KDN all take part in the rehabilitation of the extremists. Some actions are taken throughout the process, which is studying the extremist ideology's details, classifying the active members from the passive, preparing answers to the extremist ideology's details, approaching the extremists through dialogues and taking care of the extremists' family and their welfare through KEMAS (Jabatan Kemajuan Masyarakat) and Pusat Zakat.

\section{Regional Counter Terrorism Guidelines}

A study conducted by Al-Hedayah, an NGO based in Indonesia showed a guideline for counter terrorist programs (Zeiger 2016). It consists of a few key components:

\section{Push/Pull Factors and Target Selection}

The government needs to recognize the push and pull factors for an individual to get involved in Islamist extremism. This is also followed by the need to categorize the targets of extremist programs, consisting of the common public, the elites, the sympathisers and the supporters.

\section{Deep Understanding of Extremism}

Governments should recognize extreme ideologies both literally and figuratively. The extreme ideologies commonly found in Southeast Asia can basically be classified according to the one of these narratives: religious, political, social or economic. Abdullah Azzam on this matter, wrote in which his writings pointed out these ideas:

1. Religion justifies extremism.

2. Cementing belief and faith is an obligation for all Muslims.

3. Everything by the west is corrupt.

4. Retaliation is permitted.

The reading materials promoting Islamist extremism, be they printed or online, are all founded on these four points. The outcome of these four bases is a misconception of Islam in which it is believed that jihad qital (killing) is a fardh (religious duty) on every Muslim. Any Muslim who has a different say or disagree with this teaching is no longer 
a Muslim, which is why the practice of takfir (excommunicating) is popular among the Islamist extremist.

Meanwhile, in the context of a political narrative, there has to be a sovereign Islamic country in Southeast Asia, only then can Islamic law be implemented. The extremists would also stress that this Islamic country will attend to everyone. On this basis, Daesh welcomes recruits from anywhere around the globe.

\section{Identifying the Weak Points of Islamist Extremism Ideology}

Organizers of rehabilitation programs should recognize the weak points of these extreme ideologies which include:

1. Daesh actually fail to attend to foreigners who join the group.

2. Daesh's claim for authority and caliphate is illegitimate.

3. Their grounds for allowing jihad are already proven to be wrong by Muslim scholars.

\section{Programs Involving Extremists' Family Members}

To ensure the effectiveness of rehabilitation programs, support from the extremists' family members is also essential. They are invited to counselling sessions and their well-being are taken care of throughout the extremists' time in holding. This is necessary for family members have big influence over each other, and the extremists' ideology may have spread through them.

\section{Programs Upon Detained Extremists' Release}

Should a detained extremist be freed, the extremist should beforehand, be taken through a strict screening process to ensure his deradicalization is indeed successful. Inevitably, the said freed extremist should be under constant supervision and probation.

\section{The What and Why of Islamist Extremism: A Critical Analysis}

One challenge faced by western researchers is to understand the Islamist extremist ideology. This is mostly due to their secular mindset, and logical empiricism philosophy, which sees religion as a redundant factor (Mohd Hazim 2005). This makes it impossible to understand the role of faith in the making of an extremist. The outcome of their research is only from a sociological point of view.

The western researchers typically link extremism phenomenon to; first, social relationship, second, oppression, like that faced by Palestinians. Third, even if the researchers do link extremism to al-Quran and al-sunnah, it is only in a literal manner. At any rate, their studies show the extremists' fanaticism is beyond sanity (Kruglanski 2004).

\section{Influence of Worldview on A Person's Mentality}

To undo extremists' ideology is not easy. This difficulty is constituted by the worldview to which the extremists hold. This, from another perspective, reflects the 
advanced approach of Islam, which considers world view and mentality as necessities for human too and not just material needs (Abdul Rahman 2001). World view is seen by Islam as one of the factors in decision making (Hossein Nasr 1990).

Worldview is the fundamental cognitive orientation of an individual or society encompassing the whole of the individual's or society's knowledge and point of view. A worldview can include natural philosophy: fundamental, existential, and normative postulates; or themes, values, emotions, and ethics. This point of view affects the individual's or society's thoughts and actions.

Essentially, a worldview is based on: the reality and truth obtained through the study of metaphysics regarding the visible and invisible worlds, integral thinking regarding life based on religious texts (Syed Naquib 1996).

This opinion is parallel to the findings by a researcher on extremism, Kumar Ramakrishna (2009), who found that people with spiritual and religious voids tend to:

1. Long for the spiritual touch.

2. Blindly trust an extremist for guidance.

3. Commit to religion even without essential basic understandings. On these matters their eagerness is usually wrongfully fuelled with the harsh reality on the oppressed Muslims in the hands of great powers, such as faced by the Muslims in Afghanistan, Palestine, Iraq and the region of Kashmir.

4. Be driven by financial desperation.

People with these four traits are the common targets of extremists. Their groups would approach and provide the needs, then the target individuals would be asked to join gatherings. In case of disagreements, the common threats would be that the law enforcers have already set eyes on them and kept an eye on their movements. This instils fear and leaves them no other choice but to stick to the extremists.

\section{Ignorance and Misconception in Epistemology}

Theories on the emergence of extremist ideology can be grounded on the idea that ignorance is the foundation. This is inspired by the views of Syed Naquib Al-Attas and Syed Husin Al-Attas.

Muslims are required to judge every matter in a holistic and integrated manner. Evaluations and assessments are not to be static, literal, formalistic nor judgemental. Those in compliance with Islamic principles would be faith-driven, rationalistic, societal and world affirmative.

Matters stressed in the theory of ignorance are:

1. Individuals related to extremism and terrorism whether on cognitive, affective, or psychomotor levels have weak minds and are ignorant. 
2. Lack of knowledge on the correct religious epistemology leads to dense ignorance, which leads to being spiritually weak, hence strengthening stubbornness, closeness to a different point of view even if it was correct. This denseness has been mentioned in the holy Quran to be a punishment from God to those unwilling to learn properly.

3. This stubbornness when mixed by vengeance and hatred, causes an individual to be extremely hateful to the extent of taking extreme measures, which would ultimately leave impacts on the whole Muslim community.

\section{Khawarij Ideology as a Main Factor in the Understanding of the Salafi Jihad}

Research by Muhammad Haniff Hassan (2009) discovered several main contents of the Salafi Jihadi ideology:

1. The difference between Islam and every other religion. Everything must be seen in a legal formalistic manner, where a person is either Muslim or kafir or munafiq. All the destructions happening in the world is conspired by a bigger power, the Zionists. On this ground, it is believed that they must be fought.

2. The never-ending feud between Muslims and others, as mentioned in a Quranic verse that the Jews and Christians will never accept Islam.

3. Muslims are prohibited to agree with non-Muslims on no matter what. Living in a non-Muslim country is also not advisable. The only allowed reason for visiting a non-Muslim country is to preach. Learning from non-Muslims is allowed only for the sole purpose of using their own knowledge against them. Non-Muslims on the other hand, are obliged to pay jizyah (tax) to Muslims. Any form of diplomatic relationship with non-Muslim governments is prohibited.

4. All Muslims must support the Salafi Jihadis in order to establish a fully Islamic government.

5. The only reasonable way to establish an Islamic government is through weapon wielding jihad.

6. War against the non-Muslims allows targeting the public for the following reasons:

a. Non-Muslims have done the same to the Muslim public.

b. The non-Muslim public vote for the leaders from among themselves and pay taxes to their government.

c. Collateral damage is allowed in pursuit of the greater good.

7. Suicide bombing is allowed and leads to martyrdom.

\section{Similarities Between the Ideologies of Khawarij and Salafi Jihad}

Based on the findings stated above, the Salafi Jihad ideology is a reincarnation of the Khawarij. Studies have been conducted and showed the similarities shared among the two (Wagemakers 2014).

First, both are formed by young adults with short vision. This similarity, despite the time gap between the two, is undeniable. Second, both equally reject contextual 
elements in their fights. The Khawarij saw no difference between Ali and Muawiyah. Likewise, the Salafi Jihadi see all the current Islamic government as toghut (astray) and influenced by the West.

The Malaysian government is seen totally a non-Islamic. (Mohd Noor 2014). Although Malaysians are relatively peaceful, Kumpulan Militan Malaysia (KMM) decided to walk on the extreme path (Mohd Mizan 2009). Few examples can be shown for this ground:

1. KMM was established for the sole purpose of taking over the government through revolution. Members joined PAS, the only Islamic party in their eyes, discreet in because PAS would not agree to their agenda.

2. The group smuggled and stored firearms in a huge quantities for use when necessary.

3. They were responsible for bombing Hindu temples, attacking police stations, robbing banks, and murdering Dr. Joseph Fernandez for reverting Muslim women out of Islam. They were also responsible for an assault attempt on US Navy on Malaysian soil.

4. They were involved in indoctrination effort on civilians and university students.

\section{Extreme Measures and Misconception of Jihad}

Similar to Khawarij, Salafi Jihad have a tendency towards extreme measures. This is prioritized even over fellow Muslims' blood, which ultimately gave no other option to Ali, a caliph who would avoid civil war at all cost, but to fight them and lead to the battle of Nahrawan. During his final days, he warned his two sons on them. He described them to be misled and their belief would only pollute the purity of Islam. Those of the Salafi Jihad were symmetrical to Ali's words, in whose eyes suicide bombing is allowed even at the cost of innocent civilians' lives (Green 2009).

The Salafis are also reluctant to learn from orthodox scholars and texts, seeing them as taqlid and bid'ah. Instead, they follow their own scholars for their literal interpretation. Their young are kept busy with war related activities, and they grow up without sufficient basic Islamic knowledge (Eggers 2011). This insufficiency is visible in Imam Samudera's weak justifications for the Bali bombing tragedy. His short writing, " $A k u$ Melawan Terorisme" backlashed and was criticised by every orthodox Islamic movement in Indonesia for two reasons. First, his views were tightly influenced by that of Abdullah Azzam, a figure in Salafi Jihad ideology indoctrination from Afghanistan (Calvert 2007), and second; the bombing is justified with verses misinterpreted to suit his selfish vision. This misconduct is a solid proof of his lack of understanding of Maqasid, the goals of Islamic law (Amir Mualim 2004). In his book, he wrote that the bombing is a payback for the oppression on Muslims by the West (2004). He quoted, "...and wage war on all the non-believers as they do to you, and (know that) Allah is with the cautious (of their duty)" (al-Quran 9:36). Imam acknowledged the prohibition of killing innocent lives, but America and her allies crossed the line first. In another 
verse, '....and if you retaliate, let it be equivalent to what you have suffered. But if you patiently endure, it is definitely better for those who are patient" (al-Quran 16:126).

Imam Samudera claimed the Bali bombing to be in accordance to the calls for jihad and its stages, as explained in Tarbiyah Jihadiyah by Abdullah Azzam and Tafsir Ibn Katsir. The fourth and final stage, obliges the killing of every non-believers (al-Quran 9:5). This interpreted by Imam Samudera, as a license to be offensive towards all who are in favour of the West until the world is cleansed of their impurities, and no other is worshipped but Allah.

Regarding suicide, Imam Samudera's justification on that matter are a few narrations of the prophet. Ibn Nuhas recorded 16 narrations where the prophet's companions attacked the enemies with no regards of their own safety. This was supposed to be backed by a verse once read by Abu Hurairah in public, "and among them are those who sacrifice themselves for the sake of Allah..." (al-Quran 2:207).

His opinion was opposed by the Muslim scholars of Indonesia for reasons such as:

1. The typology of Dar al-Harb and Dar al-Islam is no longer relevant for this age since there are no longer major changes in international relationships. Tariq Ramadan in his book To Be a European Muslim, mentioned this typology opposes the concept of Islam being a blessing to the whole universe, and has no origin from al-Quran nor sunnah (Yoyo Hambali 2010).

2. The verses quoted by Imam Samudera were out of context and opposed their purpose. Scholars like Imam al-Qurtubi and al-Tabari explained that the permission for war is not valid unless by proper authority.

3. Islam's principle on the relationship between Muslims and non-Muslims is based on toleration and peace, not harm.

\section{Conclusion}

It is undeniable that the violent acts by JI, so allegedly in the name of Islam, have polluted the world's take on the peaceful religion. Such acts have also caused western countries to retaliate on the whole Muslim community regardless of their stand on the extremists. This henceforth requires the whole world to prepare suitable rehabilitation programs. This study has pointed out the efficiency of the programs carried out in Saudi Arabia, Singapore, and Malaysia. This is due to the combination of both soft and hard approaches. Still, Muslim scholars must inject these programs with the proper Islamic philosophy and principles. Only then will these programs prove to be fully successful.

\section{Appreciation}

These findings are part of the FRGS/1/2019/SSI03/UM/02/6 research grant entitled "Module Development on the Deradicalisation of Religious Terrorism based on the Local Malay-Muslim Approach" awarded by the Ministry of Education, Malaysia (MOE). Acknowledgment is addressed to MOE on the award of the grant so that the study will continue to achieve the objectives outlined. 


\section{References}

A New Approach? Deradicalization Programs and Counterterrorism (2010). Conference entitled Countering Violent Extremism: Learning from Deradicalization Programs in Some Muslim-Majority States, $\quad$ Mar. 1617, 2010, Amman, Jordan.

Abdul Azis Alias Imam Samudra Alias Qudama (2004). Aku Melawan Teroris, ed. Bambang S Solo: Jazeera.

Abdul Rahman Abdullah (2001). Falsafah dan Kaedah Pemikiran, Kuala Lumpur: Utusan Publication, 134-140

Ahmad Sauffiyan Abu Hassan (2016). Daesh: Kebangkitan dan Pengaruh Media Sosial, Jurnal Komunikasi Malaysian Journal of Communication, Vol. 32 (2), 381-404

Amir Mualim, (2004). Ijtihad Dan Legislasi Muslim Kontemporer, Yogyakarta: UII Press, 54-56

Azyumardi Azra (2003). Bali and Southeast Asian Islam: Debunking the Myths, dalam After Bali: The Threat of Terrorism in Southeast Asia, ed. Kumar Ramakrishna and Seng Seng Tan. Singapura: Institute of Defence and Strategic Studies, Nanyang Technological University and World Scientific Publishing Company, 52.

Boucek C. (2008). Saudi Arabia's Soft Counter Terrorism Strategy, Carnegie Endownment for International Peace, Sep. 2008, Middle East Program, Num. 97

Calvert J. (2007). The Striving Shaykh Abdullah Azzam and the Revival of Jemaah Islamiyyah Had, Journal of Religion and Society, Supplement Series 2, 122.

Eggers B.A (2011). Addressing The Cause: An Analysis of Suicide Terrorism, Master's Thesis for Colorado State University.

Ezzarqui L., (2010). De-Radicalization and Rehabilitation Program: The Case Study of Saudi Arabia, Master's Thesis for the Faculty of the Graduate School of Arts and Sciences, Georgetown University, 25-33.

Green C.A (2009). The Khawaarij and the Creed of Takfeer: Declaring A Muslim to be an Apostate and Its Effects Upon the Modern-Day Islamic Movement, Master's Thesis for The University of South Africa.

http://carnegieendowment.org/events/?fa=eventDetail\&id=1184\&prog=zgp\&proj=zte d, retrieved on Apr. 5, 2009.

Kruglanski, A. W. (2004). The Psychology of Closed Mindedness. New York: Psychology Press.

Mohd. Aslam Mizan (2016). De-Radicalization Programs in South-East Asia: A Comparative Study of Rehabilitation Programs in Malaysia, Thailand, Indonesia \& Singapore, Journal of Education and Social Sciences, Vol. 4.

Mohd. Hazim Shah Abdul Murad (2005). Epistemology Colonial: Satu Analisis Ciri Dan Kesannya, ed. Mohamad Daud Mohamad, Pascakolonialisme Dalam Pemikiran Melayu, DBP: Kuala Lumpur, 91-92. 
Mohd. Mizan Mohammad Aslam (2009). A Critical Study of Kumpulan Militant Malaysia, Its Wider Connections in the Region and the Implications of Radical Islam for the Stability of Southeast Asia, Ph.D. Thesis for Victoria University of Wellington.

Mohd. Noor Mat Yazid (2014). Colonial Policy and the Impact to the PoliticoEconomy Stability After Independence: The Case of Indonesia Under the Dutch and Malaysia Under the British, Review of History and Political Science, December 2014, Vol. 2, No. 3 \& 4, 69-84.

Muhd. Haniff Hassan (2009). Jemaah Islamiyyah Ideology: An Overview, ed. Arnauld De Borchagrave, Conflict, Community and Criminality in Southeast Asia and Australia: Assesments from the Field, A Report of CSIS Transnational Threats Project, Singapore, 76-83.

Muhd. Haziq Jani (2017). Counter Terrorist Trends and Analyses, Journal of The International Centre for Political Violence and Terrorism Research, Vol. 9, Issue 1, 18-19.

Nasr, S. H., (1990). Traditional Islam in the Modern World, London: Kegan Paul International, 13

Ramakrishna K. (2009). A Holistic Critique of Singapore's Counter-Ideological Program, Jan. (CTS Sentinel),

http://www.ctc.usma.edu/sentinel/CTCSentinel-Vol2Iss1.pdf , retrieved on Mar. 27, 2009.

Ramakrishna K. (2009). Governmental Responses to Extremism in Southeast Asia: Hard Versus Soft Approaches, ed. Arnauld De Borchagrave) Conflict, Community and Criminality in Southeast Asia and Australia: Assessments from The Field, A Report of CSIS Transnational Threats Project, Singapore, 31-36

Singh B. (2017). The Revival of Al Qaeda's Affiliate in Southeast Asia: The Jemaah Islamiyah, A Journal of the International Centre for Political Violence and Terrorism Research, 9 (5), 5-7.

Smart, N. (2001). Worldview, Crosscultural Explorations of Human Belief, Charles Sribner's sons, New York.

Syed Naquib al-Attas (1996). Opening Address, The Worldview of Islam, An Outline, ed. Sharifah Shifa al-Attas, Islam and the Challenge of Modernity, Historical and Contemporary Contexts, Kuala Lumpur: ISTAC, 28-29.

Wagemakers J. (2014). "Seceders" And "Postponers"? An Analysis of the "Khawarij" And "Murji'a" Labels in Polemical Debates Between Quietist and Jemaah Islamiyyahhadi-Salafis, ed. Jeevan Doel \& Zahir Kazmi, Contextualising Jemaah Islamiyyahhadi Thought, London: Hurst \& Co., 145-164.

Yoyo Hambali (2010) Hukum Bom Bunuh Diri Menurut Islam Radikal Dan Islam Moderat, Maslahah, Vol.1, No. 1, 40-62.

Zeiger S. (2016). Narratives and Counter-Narratives, Hedayah, Sydney. 